\title{
SEASONAL VARIATION OF OXYGEN ISOTOPIC COMPOSITION OF FIRN CORES IN THE ANTARCTIC ICE SHEET
}

\author{
by \\ Kazuhide Satow \\ (National Nagaoka College of Technology, Nishi-katakai, Nagaoka 940, Japan) \\ and \\ Okitsugu Watanabe
}

(National Institute of Polar Research, Kaga 1-9-10, Itabashi-ku, Tokyo 173, Japan)

\section{ABSTRACT}

We have investigated two $30 \mathrm{~m}$ cores at two different spots in the most heavy snow-accumulation regions on Mizuho Plateau, East Antarctica. Marked seasonal variations periodically appear in oxygen isotope records of the cores. We analyzed one core with no trace of snow melting and found it had a complete record showing a yearly change of annual net snow accumulations from 1920 through 1980. The analysis shows that a yearly variation of annual net accumulation (N.A.) has some relations with that of the annual maximum value $(\delta \max )$ of $\delta^{18} \mathrm{O}$ and that of the annual amplitude $(\Delta \delta)$ of the $\delta^{18} \mathrm{O}$-change in an annual snow layer. Power spectral analyses with respect to the variation of N.A., $\delta \max$ and $\Delta \delta$ also indicate that there is commonly a predominant periodicity of about five years.

\section{INTRODUCTION}

Various environmental problems have been threatening to ruin us, especially recently. Most of them need close study from global viewpoints. Therefore it is very urgent that we find out the past record of change of environment or climate on Earth by means of firn or ice-core analysis in the polar regions. Furthermore, knowledge of annual net snow accumulation and its variation presents important information as to the shrinkage or growth and ice-sheet dynamics of Antarctica, and helps to advance research work on flow models of ice streams.

On Mizuho Plateau of East Antarctica, characteristics of surface-depositional regime have been studied (e.g. Watanabe and Satow, 1988) and core analyses have also been carried out by Japanese Antarctic Expeditions. But the seasonal variations of physical or chemical properties of firn cores cannot commonly be seen, due to the complex interaction of low net accumulation of snow, erosion-accumulation process of surface snow by strong katabatic winds and metamorphism of accumulated snow.

This paper deals with the results of the investigation of two $30 \mathrm{~m}$ cores and their related problems. One core is from site S18 near the coast, the other from site W200 (Fig. 1). On Mizuho Plateau, the coast area near Syowa Station is in a higher accumulation zone and accumulation decreases further inland (Satow, 1985). The area north-east from Mizuho Station is also in a higher accumulation zone (Watanabe, 1978a). Both core-boring sites belong to these higher accumulation zones.

\section{FIRN CORES AT SITES S18 AND W200}

\section{Core analysis and dating}

Site S18 is located at lat. $69^{\circ} 01^{\prime} 30^{\prime \prime S}$, long. $40^{\circ} 08^{\prime} 066^{\prime \prime} \mathrm{E}$, elevation $618 \mathrm{~m}$. The result of core analysis at this site is shown in Figure 2(a). We found ice layers and lenses in the core, which show evidence of snow melting and refreezing in summer. As the figure shows, density of mixed snow and ice layers is much higher. Ice layers in the core do not always coincide with summer high peaks in ${ }^{18} \mathrm{O}$ profile.

Figure 3 shows two sketches of stratigraphy from pit studies at site S16 (554 m a.s.l.) near S18, made in January 1981 and one year later. The pits were adjacent to each other, on a site with characteristics of a percolation zone in an accumulation area (Paterson, 1981). There are some disagreements between ice layers and maximum peaks of
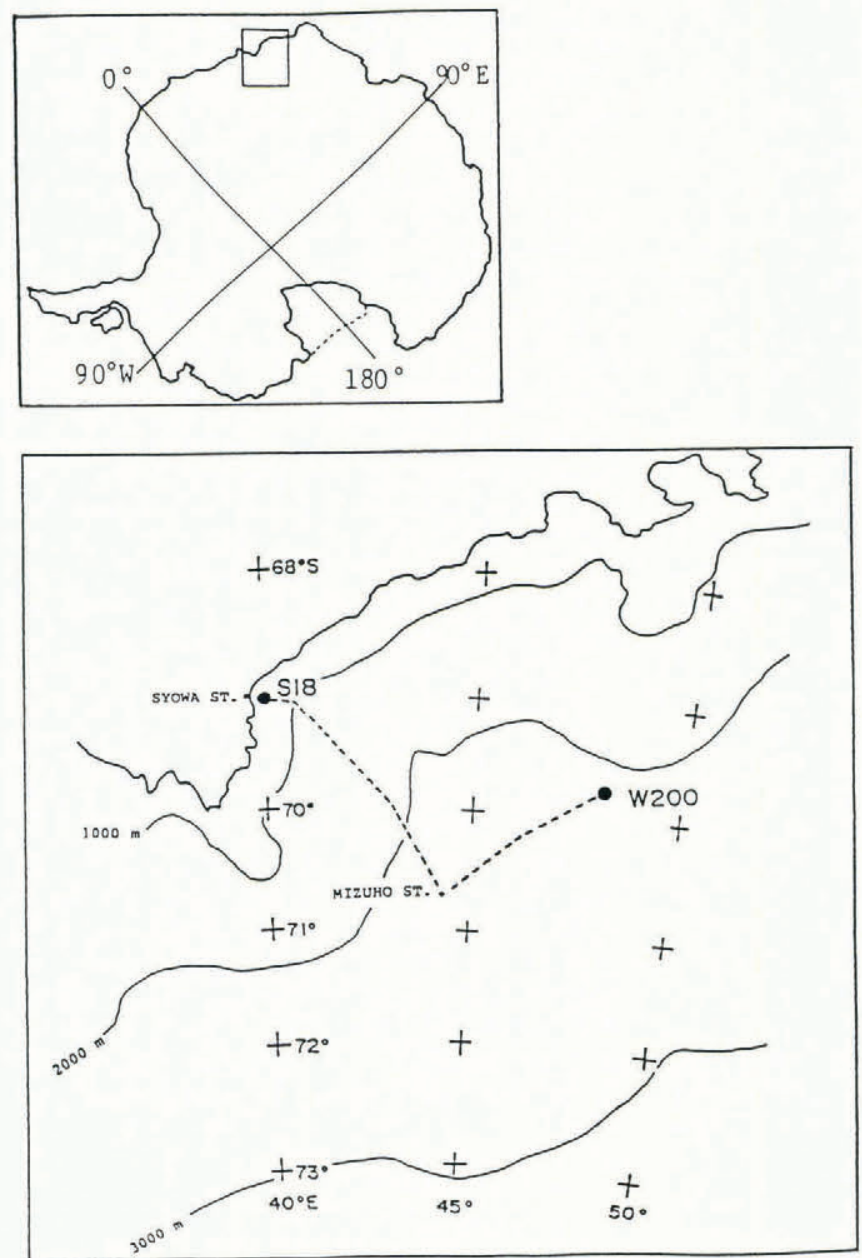

Fig. 1. Observation sites on Mizuho Plateau, East Antarctica. 
(a)

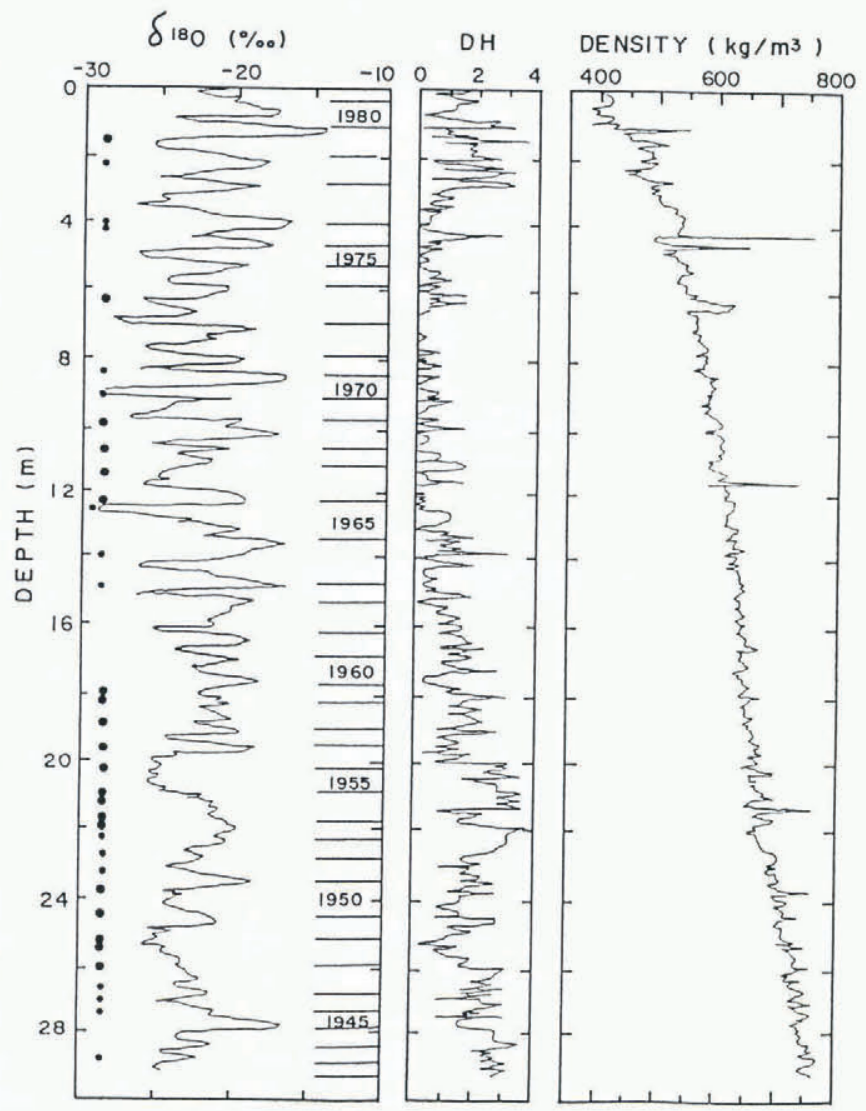

(b)

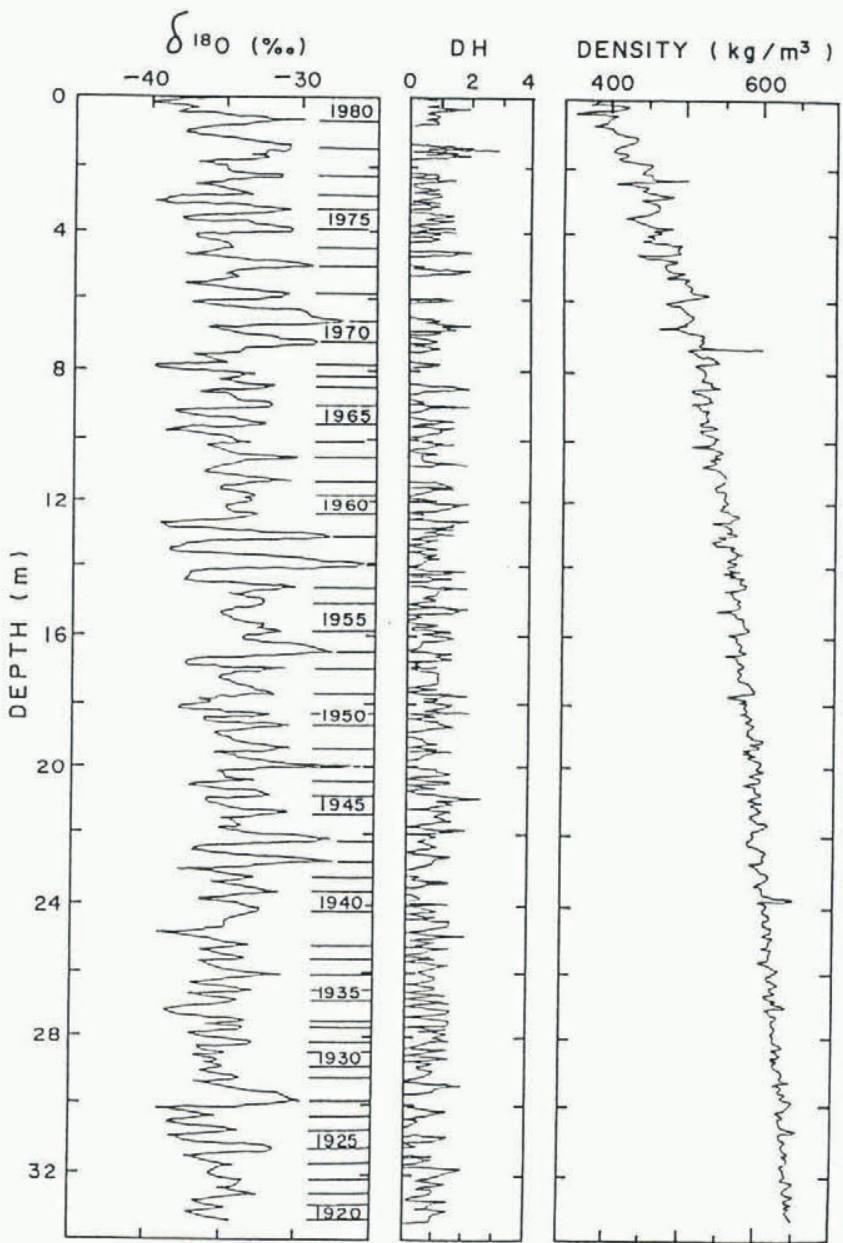

Fig. 2. Vertical profiles of oxygen isotope composition $\left(\delta^{18} \mathrm{O}\right)$, depth hoar level (DH) and firn density in $30 \mathrm{~m}$ cores at sites (a) S18 and (b) W200. Black circles in left-hand column of (a) indicate ice layers, ice lenses or ice glands.

$\delta^{18} \mathrm{O}$ seasonal variations, indicating danger in assuming that almost every ice layer represents a summer surface in a percolation zone.

One characteristic in this core shown in Figure 2(a) is that snow layers mixed with many ice layers have large values of hoar level at depth (Watanabe, 1978a). This is because growth of hoar at depth in snow is related to the temperature gradient and the cut-off of vertical movements of vapour in the snow. Using features of the $\delta^{18} \mathrm{O}$ profile, depth hoar level, density and stratigraphy, summer layers could be identified and annual layers determined, thus yielding an annual dating of the core. In the right side of $\delta^{18} \mathrm{O}$ column in Figure 2(a), the chronology of the core is shown from 1942 to 1980 .

Site W200 is located at lat. $69^{\circ} 35^{\prime} 26^{\prime \prime S}$, long. $48^{\circ} 50^{\prime} 10^{\prime \prime} \mathrm{E}$, elevation $2165 \mathrm{~m}$. Figure 2(b) shows the result of the core analysis at W200. We can see no melting phenomena such as ice layers or ice lenses in the visual stratigraphy. Snow density was $400 \mathrm{~kg} \mathrm{~m}^{-3}$ at the upper part of the core, gradually increasing with depth. But its rate of increase was lower and the amplitude of density variation was smaller compared with the S18 core.

The ${ }^{18} \mathrm{O}$ profile shows typical seasonal variations. Judging by the features of $\delta^{18} \mathrm{O}$ profile, depth hoar level, density and stratigraphy, we can easily determine annual layers, and decide a yearly dating of the core. The chronology from 1920 to 1980 of the core is shown in the right side of $\delta^{18} \mathrm{O}$ column in Figure 2(b).

Relationships between annual net accumulation, firn density and depth hoar level

Yearly variations of annual net accumulation at S18 were obtained for 39 years from 1942 to 1980 (Fig. 4(a)).
The small upper curve in this figure indicates deviation from the mean annual net accumulation by the stake method in the coastal region from S16 toward Mizuho Station (Satow, 1985). This region $(550-1800 \mathrm{~m}$ a.s.1.) is an area of higher accumulation. The difference resulted from averaging each deviation of annual mean surface net accumulation at about 80 sites from 1968 to 1980 . The coefficient of correlation between the two graphs in Figure 4 (a) $(1968-80)$ is 0.43 . The mean annual net accumulation at S18 for 39 years $(1942-80)$ was $465 \mathrm{~kg} \mathrm{~m}^{-2}$ and its standard deviation was $163 \mathrm{~kg} \mathrm{~m}^{-2}$. Since the surface snow density is about $400 \mathrm{~kg} \mathrm{~m}^{-3}$, annual snow accumulation depth is $1.2 \mathrm{~m}$ and shows a good correspondence with the result of stake measurements of snow.

There is little correlation between oxygen isotopic composition $\left(8^{18} \mathrm{O}\right)$, depth hoar level $(\mathrm{DH})$ and snow density $(\Delta \rho$ : the deviation from regression density-curve) of 368 samples in a $30 \mathrm{~m}$-long core at S18.

The mean $\delta^{18} \mathrm{O}$ value of 368 samples in the core was $-21.9 \%$ and its standard deviation was $2.6 \%$. The mean minimum peak value $(\delta \mathrm{min})$ of $\delta^{18} \mathrm{O}$ profile in an annual snow layer was $-24.9 \%$ for 39 years, the mean of its maximum peak value $(\delta \mathrm{min})$ was $-19.5 \%$, and the mean of its annual oxygen amplitude $(\Delta \delta=\delta \max -\delta \min )$ was $5.4 \%$.

As stated above, annual layers were determined and the year-to-year variation of snow accumulations at site W200 was also obtained for 61 years from 1920 to 1980 (Fig. $4(b))$. The upper right-hand graph in this figure, like that in Figure 4(a) indicates results from stakes; the coefficient of correlation between the two graphs was 0.4 for 13 years (1968-80). The mean annual net accumulation at W200 was $308 \mathrm{~kg} \mathrm{~m}^{-2}$, standard deviation $97 \mathrm{~kg} \mathrm{~m}^{-2}$.

We examined the relationships between $\delta^{18} \mathrm{O}$, depth 


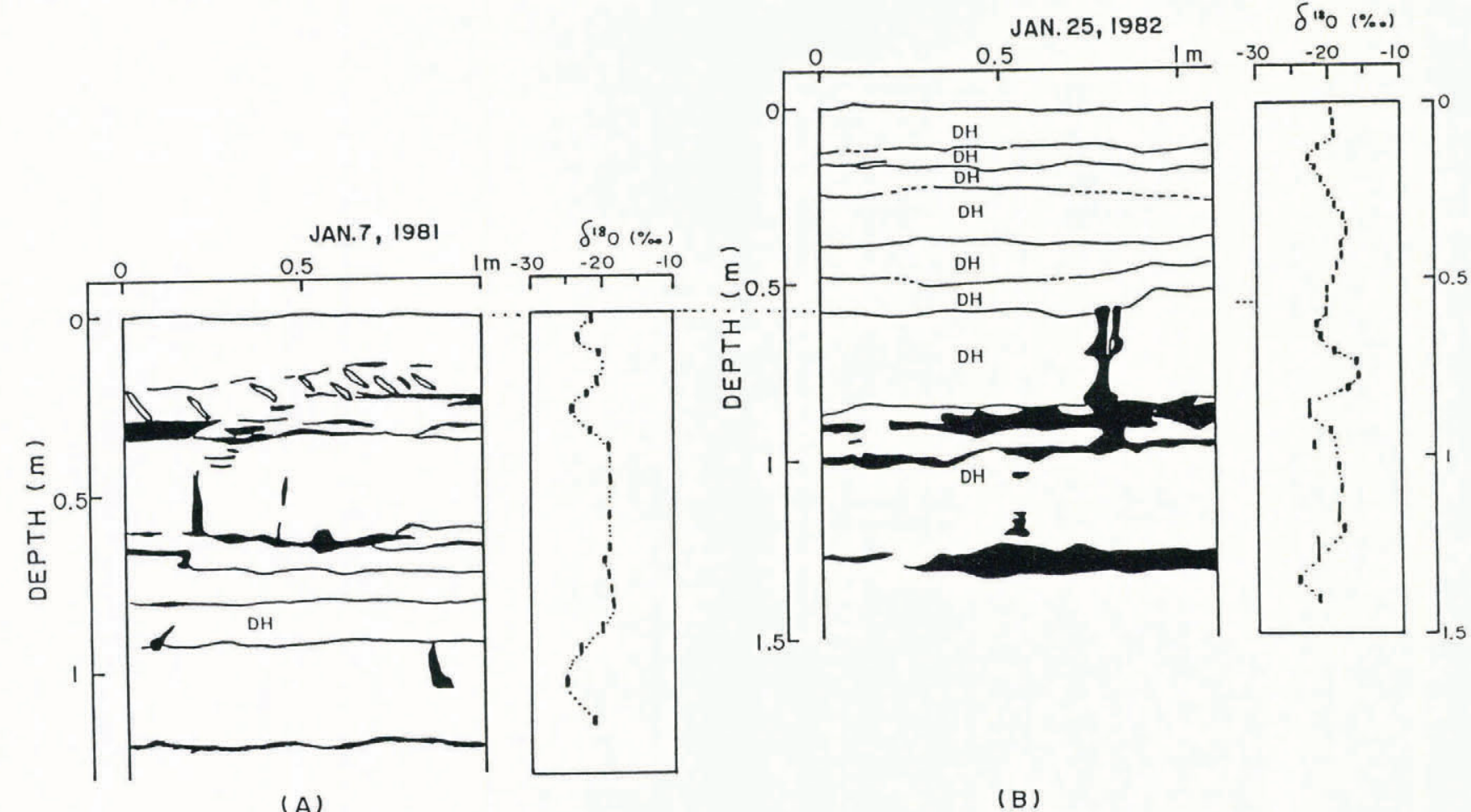

(A)

(B)

Fig. 3. Stratigraphy by pit study and oxygen isotopic profile at site S16, near S18. (A): 7 January 1981. (B) 25 January 1982. Black areas show ice layers, ice lenses or ice glands: "DH" indicates a depth hoar layer.

hoar level $(\mathrm{DH})$ and density $(\Delta \rho$ : deviation density) of 445 samples in the $30 \mathrm{~m}$ core. The coefficient of correlation between $\mathrm{DH}$ and $\Delta \rho$ was -0.43 , and other mutual relations were much lower.

As to the $\delta^{18} \mathrm{O}$ profile at W200, the mean value of 445 samples in the $30 \mathrm{~m}$ long core was $-34.2 \%$, standard deviation $2.6 \%$. The mean minimum peak value $(8 \mathrm{~min})$ of $\delta^{18} \mathrm{O}$ profile in an annual firn layer was $-37.0 \%$ for 611

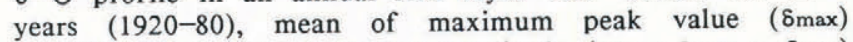
$-31.6 \%$, mean annual oxygen amplitude $\left(\Delta \delta=\delta \max -\delta_{\min }\right)$ was $5.4 \%$.
Next we investigated the relationships between the year-to-year variations of the annual net accumulations (N.A.) and $\delta^{18} \mathrm{O}$ for 61 years $(1920-80)$ at W200 (Fig. 5). Variations of N.A., $\delta \max$ and $\Delta \delta$ can be seen to show a similar tendency. We obtained the coefficient (R) of correlation as follows: $\mathrm{R}\left(\mathrm{N} . \mathrm{A} .-\delta_{\max }\right)=0.34, \mathrm{R}(\mathrm{N} . \mathrm{A} .-\Delta \delta)=0.34$, $R(\delta \min -\Delta \delta)=-0.51$ and $R\left(\delta_{\max }-\delta \min \right)=0.03$. The mean of autumn net accumulation was $161 \mathrm{~kg} \mathrm{~m}^{-2}$, that of spring net accumulation $147 \mathrm{~kg} \mathrm{~m}^{-2}$.

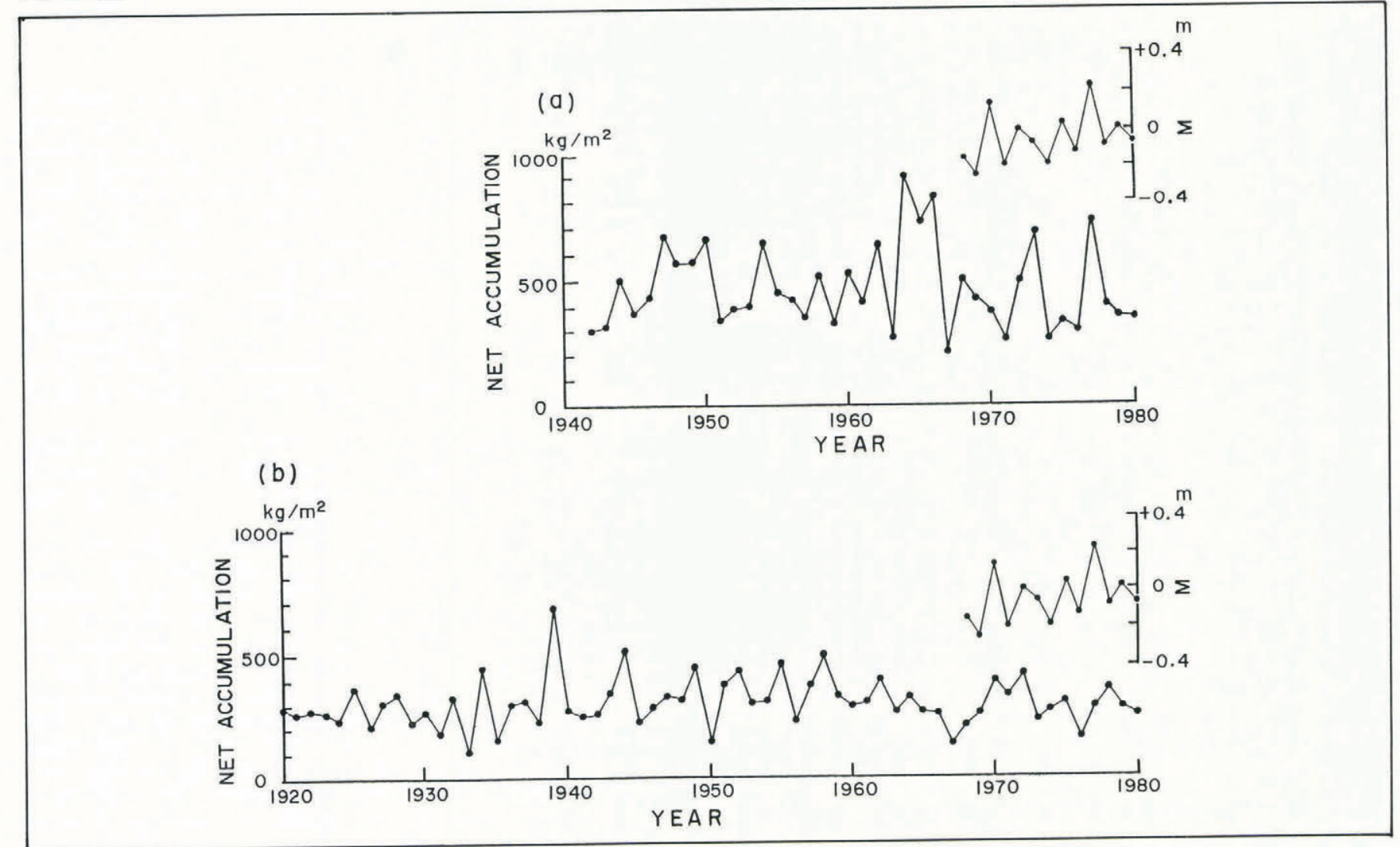

Fig. 4. Year-to-year variations of annual net accumulation: (a) 1942-80 at site S18; (b) 1920-80 at site W200. 


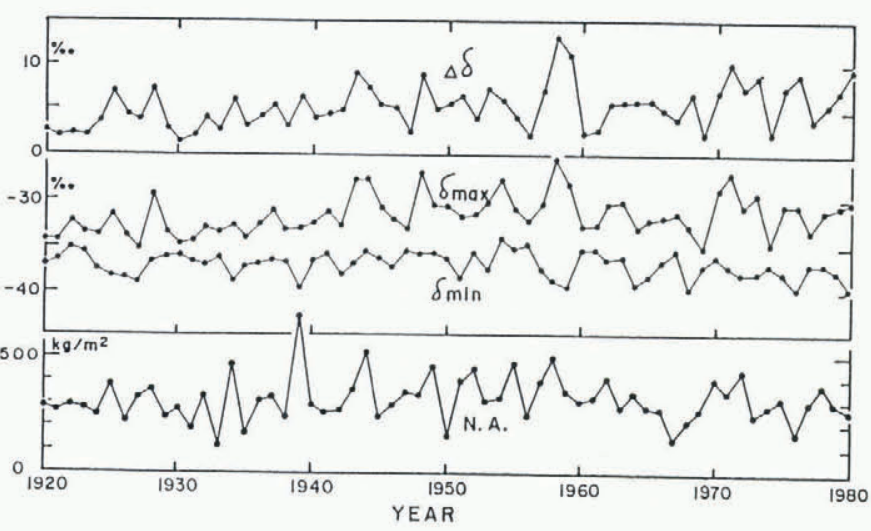

Fig. 5. Year-to-year variations of annual net accumulation (N.A.), annual minimum ( $\delta \mathrm{min})$ of $\delta^{18} \mathrm{O}$, annual maximum ( $\delta$ max) of $\delta^{18} \mathrm{O}$ and the annual $\delta^{18} \mathrm{O}$ amplitude $(\Delta \delta=\delta \max -\delta \mathrm{min})$ in an annual firn layer of a $30 \mathrm{~m}$ core, site W200.

\section{DISCUSSIONS}

For the purpose of getting dominant periodicities of variation of the annual net accumulation at W200, spectral analysis by the Maximum Entropy Method (MEM) was applied to a series of 61 year values in 1920-80. MEM has an advantage of high resolution for short series (e.g. Ulrich and Bishop, 1979; Hino, 1977). Spectral distribution for the annual net accumulation (N.A.) is shown in the lower column of Figure 6, together with that for $\delta$ max variation (middle column) and $\Delta \delta$ variation (upper column). In annual net accumulation, the predominant peaks 1 and 2 show 4.7-year and 2.5-year periodicities respectively. Peak 1 in $\delta$ max spectral distribution shows a 4.7-year cycle. In $\Delta \delta$ distribution, peaks 1,2 and 3 show respectively $7.4,4.8$ and 2.3-year periodicities. There is a common periodicity of 4.7-4.8 years. We have not yet verified the existence of

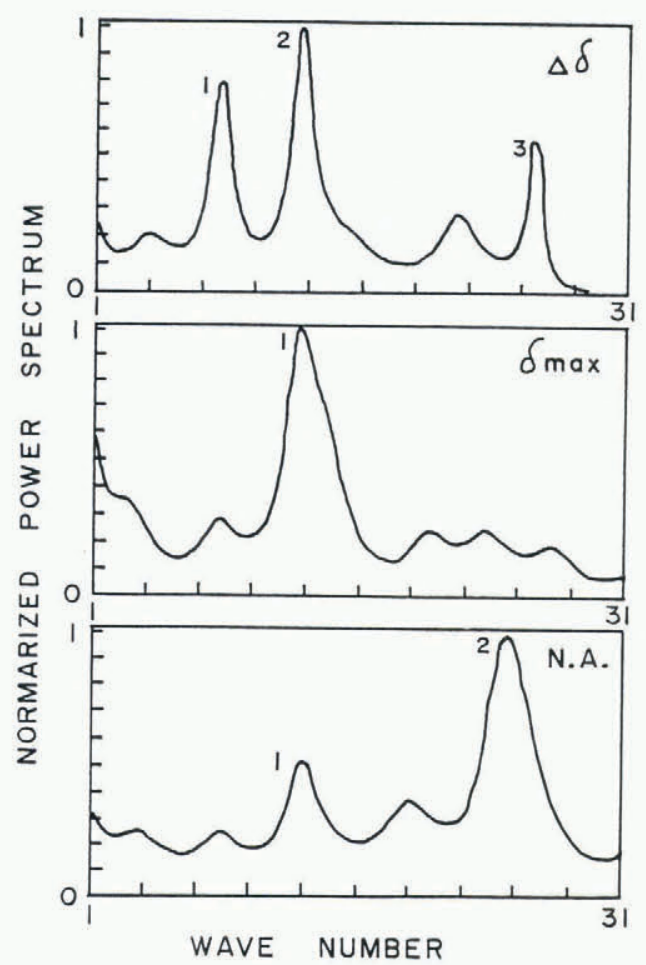

Fig. 6. Power spectra of yearly variations of annual net accumulation (N.A.), annual minimum ( $\delta$ min) of $\delta^{18} \mathrm{O}$ and annual $\delta^{18} \mathrm{O}$ amplitude $(\Delta \delta)$ in an annual layer of a $30 \mathrm{~m}$ core, site $\mathrm{W} 200$. The vertical axis shows relative power spectrum where the maximum power value is 1 in each column. other glacio-meteorological phenomena with similar periodicity, but Bryazgin (1986) stated that 5-6 and 19-22 year cycles appeared in annual precipitation at some stations in Antarctica. Peak 2 in N.A. corresponds to peak 3 in $\Delta \delta$.

There are some investigations on $\delta^{18} \mathrm{O}$ temperature relationships (Benoist and others, 1982; Lorius, 1983; Robin, 1983; Peel and others, 1988), and a few papers (Young and others, 1982; Morgan, 1985) dealing with temperatureaccumulation relationships say that accumulation has a positive correlation with temperature in Antarctica. Thus we can outline a scenario as follows (see Fig. 7).

With the onset of summer, the area of open sea increases, the distance from open sea to the bore site on the ice sheet is shorter, and $\delta^{18} \mathrm{O}$ values of snowfalls in summer become higher. Actually, the seasonal variations of new snow at Syowa Station near the coast, and of drifting snow at Mizuho Station on the plateau (about $260 \mathrm{~km}$ from the coast), is controlled not only by seasonal variations of atmospheric temperature, but also by changes in distance from the coast to the open sea (Kato and others, 1978) The $\delta^{18} \mathrm{O}$ maximum value in summer affects strongly the annual amplitude of $\delta^{18} \mathrm{O}$ variation $(\Delta \delta)$. On the other hand, some relationship is likely between distance from open sea in summer and change of meteorological circumstances, for example, activities of cyclones over the Southern Ocean. In fact, we have had much heavy snow and sampled $\delta^{18} \mathrm{O}$ rich snow at Syowa Station during the approach of cyclones (Kato and others, 1978).

The reason why $\delta^{18} \mathrm{O}$ minimum value $(\delta \mathrm{min})$ has low correlation with the other factors may be explained as follows. On the ice sheet, where the bore sites are located, the prevailing wind with east or south-east direction is blowing constantly throughout the year (Watanabe, 1978b). Therefore $\delta^{18} \mathrm{O}$ poor snow from far inland is transported and deposited by the wind. So the $\delta$ min value becomes lower and more complicated than that of original snowfalls at the site.

\section{CONCLUDING REMARKS}

Cores from high accumulation regions on Mizuho Plateau, East Antarctica, with annual layers for 39 and 61 years, were distinguished by seasonal isotopic cycles, together with depth hoar level of firn, deviation of firn density and stratigraphic features. We show that, in percolation zones, not every ice layer or ice lens indicating melting corresponds to a summer surface. The annual net accumulation and its year-to-year variations obtained from core analysis show a good correspondence to those from the measurements by stake method.

It is remarkable that the scatter of $\delta^{18} \mathrm{O}$ values and the average of $\delta^{18} \mathrm{O}$ annual amplitudes $\left(\delta_{\max }-\delta_{\min }\right)$ were exactly the same for both cores, while $\delta^{18} \mathrm{O}$ values differ by 12.3\% . For W200-core, there is a correlation between firn density and depth hoar level. A year-to-year variation of annual net snow accumulation (N.A.) at site W200 was obtained in 1920-80. This variation has a little correlation between that of the $\delta^{18} \mathrm{O}$ maximum $(\delta \max )$ and that of the $\delta^{18} \mathrm{O}$ annual amplitude $(\Delta \delta)$ in an annual firn layer. Power spectral analyses with respect to the year-to-year variation of N.A., $\delta \max$ and $\Delta \delta$ indicate a common periodicity of about 5 years.

Similar comparisons as mentioned above need to be made with other sites that have long records of seasonal $\delta^{18} \mathrm{O}$ variations and annual net accumulations in many different regions of Antarctica, yielding more information on climatic changes over the Antarctic ice sheet.

\section{REFERENCES}

Benoist, J.P., J. Jouzel, C. Lorius, L. Merlivat, and M. Pourchet. 1982. Isotopic climatic record over the last $2.5 \mathrm{ka}$ from Dome C, Antarctica, ice cores. Ann. Glaciol., 3, 17-22.

Bryazgin, N.N. 1987. Method of preparing monthly charts of atmospheric precipitation in Antarctica. In Dolgin, I.M., ed. Climate of Antarctica. Rotterdam, A.A. Balkema, 109-116. 


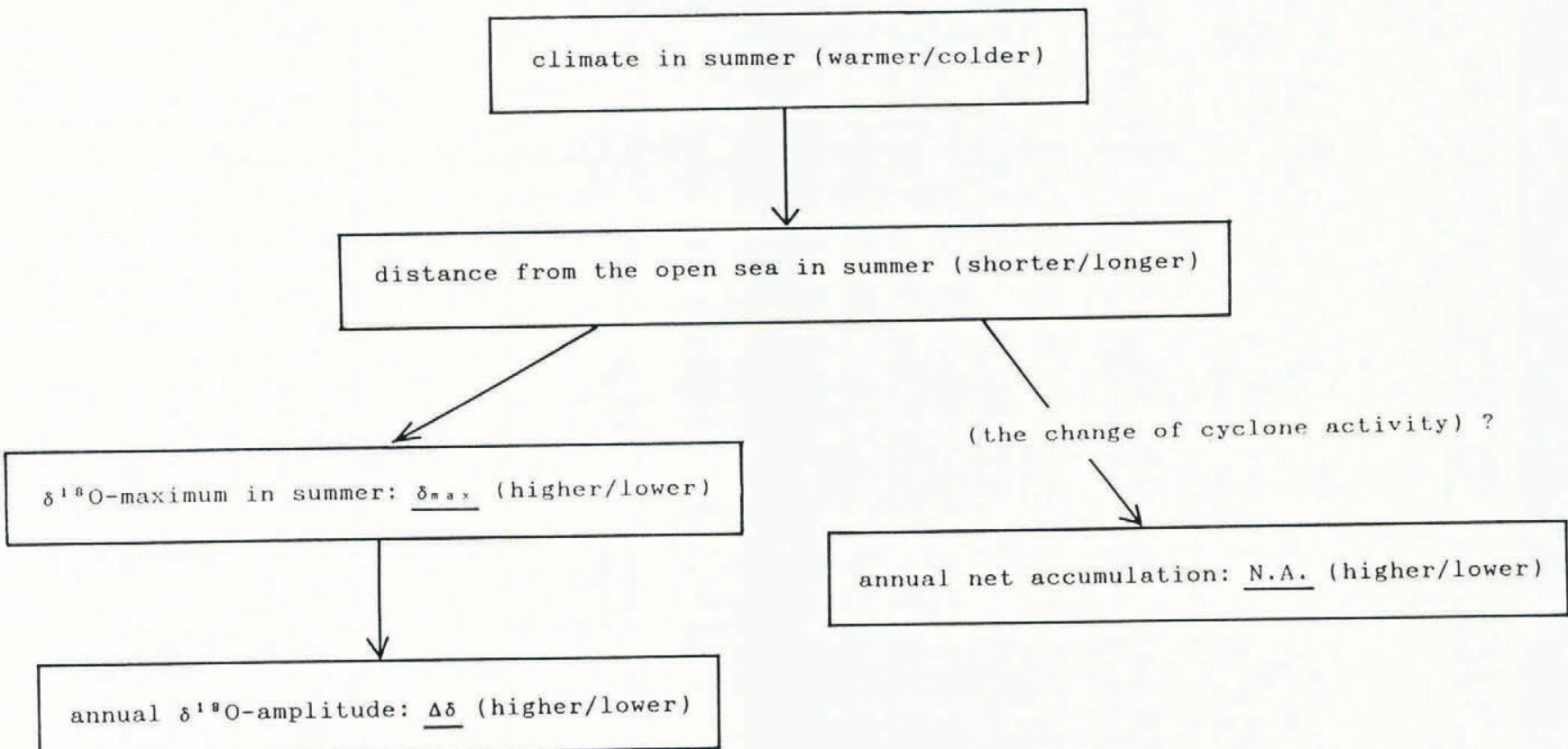

Fig. 7. Relationships between annual net accumulation (N.A.), annual maximum ( 8 max) and annual $\delta^{18} \mathrm{O}$ amplitude $(\Delta \delta)$ of snowfalls on the ice sheet.

Hino, M. 1977. Spectral analysis. Tokyo, Asakura Shoten. [In Japanese.]

Kato, K., O. Watanabe, and K. Satow. 1978. Oxygen isotopic composition of the surface snow in Mizuho Plateau. Mem. Nat. Inst. Polar Res. Spec. Issue 7, 245-254.

Lorius, C. 1983. Antarctica: survey of near-surface mean isotopic values. In Robin, G. de Q., ed. The climatic record in polar ice sheets. Cambridge, etc., Cambridge University Press, 52-56.

Morgan, V.I. 1985. An oxygen isotope-climate record from the Law Dome, Antarctica. Climatic Change, 7(4), 415-426.

Paterson, W.S.B. 1981. The physics of glaciers. Second edition. Oxford, etc., Pergamon Press.

Peel, D.A., R. Mulvaney, and B.M. Davison. 1988. Stableisotope/air-temperature relationships in ice cores from Dolleman Island and the Palmer Land plateau, Antarctic Peninsula. Ann. Glaciol., 10, 130-136.

Robin, G. de Q. 1983. The climatic record from ice cores. In Robin, G. de Q., ed. The climatic record in polar ice sheets. Cambridge, etc., Cambridge University Press, 180-195.

Satow, K. 1985. Variability of surface mass balance in the Mizuho Plateau, Antarctica. Mem. Nat. Inst. Polar Res. Spec. Issue 39, 132-140.

Ulrich, T.J. and T.N. Bishop. 1979. Maximum entropy spectral analysis and autoregressive decomposition. Pure Appl. Geophys. Spec. Issue 115, 1463-1491.

Watanabe, O. 1978a. Distribution of surface features of snow cover in Mizuho Plateau. Mem. Nat. Inst. Polar Res. Spec, Issue 7, 44-62.

Watanabe, O. 1978b. Stratigraphic studies of the snow cover in Mizuho Plateau. Mem. Nat. Inst. Polar Res. Spec. Issue 7, 154-181.

Watanabe, O. and K. Satow. 1988. Depositional regime of the katabatic slope from Mizuho Plateau to the coast, East Antarctica. Ann. Glaciol., 10, 188-192.

Young, N.W., M. Pourchet, V.M. Kotlyakov, P.A. Korolev, and M.B. Dyugerov. 1982. Accumulation distribution in the IAGP area, Antarctica: $90^{\circ} \mathrm{E}-150^{\circ} \mathrm{E}$. Ann. Glaciol., 3 , 333-338. 